\title{
HABILIDADE SOCIAL E A TEORIA DOS CAMPOS
}

\section{RESUMO}

O problema da relação entre os atores e as estruturas sociais onde eles estão imersos é fundamental para a teoria sociológica. Este artigo sugere que o foco "neo-institucionalista" sobre os campos, domínios ou jogos proporciona uma visão alternativa para se pensar sobre esse problema com ênfase na construção de ordens locais. Este artigo critica o conceito de atores tanto na escolha racional quanto nas versões sociológicas dessas teorias. É desenvolvida, aqui, uma visão mais sociológica da ação, chamada de "habilidade social". A idéia de habilidade social se origina do interacionismo simbólico e é definida como a habilidade de induzir a cooperação dos outros. Essa idéia é elaborada para sugerir o quanto os atores são importantes na construção e na reprodução de ordens locais. Proponho mostrar como seus elementos já informam o trabalho existente. Ao final, demonstro como a idéia pode sensibilizar os acadêmicos para o papel dos atores no trabalho empírico.

\section{Neil Fligstein}

University of California - Berkeley

\begin{abstract}
The problem of the relationship between actors and the social structures in which they are embedded is central to sociological theory. This paper suggests that the "new institutionalist" focus on fields, domains, or games provides an alternative view of how to think about this problem by focusing on the construction of local orders. This paper criticizes the conception of actors in both rational choice and sociological versions of these theories. A more sociological view of action, what is called "social skill", is developed. The idea of social skill originates in symbolic interactionism and is defined as the ability to induce cooperation in others. This idea is elaborated to suggest how actors are important to the construction and reproduction of local orders. I show how its elements already inform existing work. Finally, I show how the idea can sensitize scholars to the role of actors in empirical work.
\end{abstract}

PALAVRAS-CHAVE Habilidade social, teoria dos campos, imersão social, neo-institucionalismo, relação ator-estrutura. KEYWORDS Social skills, theory of fields, embeddedness, new institutionalist, relationship actor-structure. 


\section{INTRODUÇÃO}

Na teoria sociológica clássica, a reprodução e a mudança sociais são explicadas, tipicamente, pela estrutura social. Essa visão tem o efeito de transformar as pessoas em agentes da estrutura que exercem pouco efeito independente sobre a constituição de seu mundo social. Nos últimos 20 anos, houve uma renovada tentativa teórica de estabelecer um papel independente para os atores sociais na mudança e reprodução sociais. Esse debate tem sido desenvolvido em torno de questões que relacionam a estrutura e os atores ou, como foi algumas vezes expresso, o problema dos agentes e das estruturas (Giddens, 1984; Sewell, 1994; Alexander e Smelser, 1987). O debate tem sensibilizado os acadêmicos em relação ao importante papel que as pessoas reais exercem na reprodução da vida social. Contudo, após os pesquisadores terem produzido vários livros e artigos, muitos desenvolvidos em um nível um tanto quanto abstrato, parece haver pouco consenso geral quanto à maneira de pensar essas questões, e, certamente, não existe um programa positivo para a pesquisa social. ${ }^{1}$

Este artigo se inclui nessa discussão de duas formas. Primeiro, afirmo que se pode encontrar nas várias teorias "neo-institucionalistas" das ciências sociais um importante conjunto de ferramentas conceituais úteis para repensar as estruturas e a ação. Em segundo lugar, desenvolvo uma visão sociológica da ação, que se origina tanto da literatura empírica quanto da teórica, que aborda diretamente o problema da ação. O conceito de ação proposto aqui, que tem suas raízes no interacionismo simbólico, pode ser denominado habilidade social. ${ }^{2} \mathrm{~A}$ idéia de habilidade social é que os atores precisam induzir a cooperação dos outros. A habilidade de motivar os outros a tomar parte em uma ação coletiva é uma habilidade social que se prova crucial para a construção e reprodução de ordens sociais locais.

Essa idéia pode ser utilizada para compreender como identificar a contribuição distinta dos atores, independentemente de estarem defendendo um conjunto existente de arranjos sociais ou impondo ou negociando uma nova ordem. O propósito de apresentar a idéia de habilidade social é fornecer um microfundamento sociológico, em oposição ao individualismo metodológico, para utilizar teorias neo-institucionalistas. A vida social gira em torno de obter uma ação coletiva, e isso requer que os participantes dessa ação sejam induzidos a cooperar. Algumas vezes se utilizam coerções e sanções para compelir os outros. Entretanto, muitas vezes, os atores estratégicos hábeis proporcionam identidades e quadros culturais para motivar os outros. Gostaria de desenvolver essas idéias de forma que tenham implicações empíricas na maneira como estudamos a formação de campos ao longo de uma ampla variedade de cenários.

A principal contribuição deste artigo é sintetizar esclarecimentos conceituais já existentes na literatura para estimular uma visão mais coerente do quanto podem progredir as abordagens sociológicas institucionalistas. Não proponho oferecer aqui uma teoria completamente desenvolvida para a iniciativa dos atores ou instituições, nem apresentar uma série de hipóteses comprováveis. Em vez disso, proporciono um esquema conceitual abstrato que fornece aos sociólogos empíricos um conjunto de ferramentas para ajudá-los a analisar o papel dos atores no surgimento, estabilidade e transformação de vários tipos de ordens sociais locais. O cerne deste artigo é uma tentativa de desenvolver uma visão interacionista simbólica da ação ao mesmo tempo estratégica e baseada em fornecer atores com identidades coletivas como motivação para a ação. Esse também é o propósito de outros trabalhos, como os de Emirbayer e Goodwin (1994), Emirbayer e Mische (1999), Hays (1994), Joas (1996) e Sewell (1992, p. 16-19). ${ }^{3}$

Este artigo impulsiona esse projeto em duas frentes. $\mathrm{Na}$ primeira, integro a literatura existente sobre a ação estratégica na sociologia para descrever as táticas que os atores sociais utilizam visando conseguir a cooperação dos outros. Assim, por exemplo, analiso como o "quadro" ["framing"] (Snow et al., 1992), a definição de agenda ["agenda setting"] (Lukes, 1974), a intermediação ["brokering"] (Gould, 1993) e a "ação robusta" (Padgett e Ansell, 1992) descrevem alternativas de formas estratégicas de ação. Afirmo que o que todas essas táticas têm em comum são atores assumindo o ponto de vista de outros atores para persuadi-los a cooperar. $\mathrm{Na}$ segunda, relaciono explicitamente o projeto da ação para o interacionismo simbólico ao projeto neo-institucionalista de compreensão das ordens ou campos locais. Meu interesse aqui é demonstrar o que atores estratégicos hábeis farão em diferentes condições de poder e incerteza. Os atores sociais são sempre importantes para a reprodução dos campos. Em geral, a reprodução dos campos depende do desempenho habilidoso dos atores em organizações dominantes (Giddens, 1984). Mas, em condições de crise ou formação, os empreendedores institucionais podem criar sistemas completamente novos de significado. Esses empreendedores são atores estratégicos hábeis que encontram formas de induzir grupos muito diferentes a cooperar colocando-se na posição dos outros e criando significados que exercem apelo a um 
grande número de atores. Esses momentos são o objeto de muitos de nossos estudos empíricos da política, movimentos sociais, empresas e mercados.

Por quase 20 anos houve um interesse crescente das ciências sociais para explicar como as instituições sociais, definidas como regras que produzem a interação social, surgem, permanecem estáveis e se transformam. ${ }^{4}$ Apesar das diferenças, todas as teorias neo-institucionalistas apresentam pontos em comum (Hall e Taylor, 1996). Elas se concentram na construção de ordens sociais locais, que poderiam ser chamadas de "campos", "arenas" ou "jogos". ${ }^{5}$ As teorias neo-institucionalistas são construções sociais no sentido de abordarem a criação de instituições como o resultado da interação social entre atores se confrontando em campos ou arenas. Mais importante, regras preexistentes de interação e distribuição de recursos agem como fontes de poder e, quando combinadas com um modelo de atores, servem como a base na qual as instituições são construídas e reproduzidas. Uma vez existentes, as instituições tanto capacitam quanto coagem os atores sociais. Atores privilegiados podem utilizar as instituições para reproduzir sua posição. Os atores podem usar as instituições existentes para fundar novas arenas de ação. Atores sem recursos são, na maioria das vezes, coagidos por instituições, mas, em certas circunstâncias, podem utilizar as regras existentes de forma não planejada para criar novas instituições. Os pontos em comum cunhados pela "teoria neo-institucionalista" ao afirmar que o nível apropriado de teorização se inclui na dimensão meso, isto é, se concentram na construção de ordens sociais locais, podem ser aplicados a uma ampla variedade de cenários de pesquisa. Grande parte da ciência social empírica nos campos da sociologia política, sociologia econômica, sociologia organizacional e movimentos sociais se refere à produção de novos campos ou à transformação de campos antigos. Os acadêmicos que trabalham nessas subáreas precisam definir seu campo de interesse específico e entender as instituições "locais", quem são os participantes e quais são seus recursos.

Meu principal interesse diz respeito ao modelo de ação nessas teorias. A visão sociológica da ação proposta aqui se concentra na tentativa de um conjunto de atores de obter a cooperação de outros atores. Há dois grupos relevantes com os quais os atores trabalham para obter a cooperação: aqueles de um determinado grupo ou organização (membros) e aqueles existentes em outras organizações (o campo). As pessoas que atuam como líderes em grupos devem estabilizar suas relações com os membros de seu próprio grupo para fazer com que ajam de forma coletiva e devem desenvolver seus movimentos estratégicos mais gerais na direção de outras organizações em seu campo ou domínio. A habilidade da parte dos atores para analisar e obter essa cooperação pode ser vista genericamente como uma habilidade social. Todos os seres humanos têm alguma habilidade social em função de sua atuação em grupos. Contudo, sabemos que alguns atores são socialmente mais hábeis em obter a cooperação dos outros, atuando com atores mais poderosos e sabendo em geral como construir coalizões políticas na vida.

As teorias neo-institucionalistas enfatizam que as regras e os recursos existentes são os elementos constitutivos da vida social. Gostaria de acrescentar que a capacidade dos atores de utilizar habilmente as regras e os recursos também faz parte do cenário. Em algumas situações nas quais regras e recursos têm um peso muito maior na direção dos grupos mais poderosos, a habilidade social pode não fazer muita diferença. Na presença de mais incertezas ou de turbulência social, a habilidade social pode ter uma função crucial para manter as ordens locais unidas. Além disso, no surgimento das ordens, a habilidade social normalmente tem destaque. Não é por acaso que falamos de empreendedores na vida econômica, social e política. Esses atores são pessoas de visão que criam novas coisas. Eles não somente têm uma idéia, mas devem utilizar essa idéia para induzir a cooperação entre os outros (DiMaggio, 1988). Utilizando os termos de Giddens (1984), os "desempenhos hábeis" dos atores sociais estão no âmago da produção e reprodução da vida social. Contudo, em algumas condições sociais, os desempenhos hábeis de certos atores podem ser mais cruciais do que em outras condições.

A visão da dimensão meso da vida social que provém dos neo-institucionalismos e a idéia de habilidade social oferecem uma abordagem para pensar a questão da estrutura-agente. Começo analisando como as teorias neoinstitucionalistas nos oferecem uma visão da dimensão meso da construção de ordens locais. Critico o modelo de ação tanto na versão de escolha racional quanto sociológica dos neo-institucionalismos. Em seguida, o modelo de habilidade social é elaborado. Ofereço proposições sobre os diferentes modos de comportamento dos atores estratégicos, que varia dependendo de suas posições nos campos. Analiso o quanto essas proposições afetam diretamente a maneira como formulamos a pesquisa e, finalmente, considero o escopo empírico desse tipo de conceitualização examinando alguns exemplos da literatura existente que ilustram tanto as proposições quanto as questões de pesquisa. 


\section{PONTOS EM COMUM NO “NEO-INSTITUCIONALISMO”}

As instituições são regras e significados compartilhados (implicando que as pessoas estão conscientes delas ou que elas podem ser conscientemente conhecidas) que definem as relações sociais, ajudam a definir quem ocupa qual posição nessas relações e orientam a interação ao proporcionar aos atores quadros cognitivos ou conjuntos de significados para interpretar o comportamento dos outros. Elas são intersubjetivas (podem ser reconhecidas pelos outros); cognitivas (dependem das habilidades cognitivas dos atores); e, em um certo nível, requerem a auto-reflexão dos atores (para uma boa revisão das várias bases das instituições, veja Scott, 1996, capítulo 3). As instituições podem, é claro, afetar as situações dos atores com ou sem seu consentimento ou compreensão.

Os pontos em comum centrais nas teorias neo-institucionalistas se concentram no conceito de ordens sociais locais, que podem ser chamadas de "campos" (Bourdieu, 1977; Bourdieu e Wacquant, 1992), "campos organizacionais" (DiMaggio e Powell, 1983), "setores" (Meyer e Scott, 1983) ou "jogos" (Axelrod, 1984). Os campos se referem a situações nas quais grupos organizados de atores se reúnem e desenvolvem suas ações recíprocas face a face. As teorias neo-institucionalistas se interessam pelo modo como os campos de ação surgem, permanecem estáveis e podem ser transformados. A produção de regras em uma arena social trata da criação das instituições. ${ }^{6} \mathrm{~A}$ institucionalização é o processo pelo qual as regras passam de abstrações a constituintes de repetidos padrões de interação em campos (Jepperson, 1991). ${ }^{7}$

Por que os atores desejam produzir padrões estáveis de interação? Minha posição é que o processo de construção de instituições ocorre no contexto de atores poderosos tentando produzir regras de interação para estabilizar sua situação em relação a outros atores poderosos e menos poderosos. Os campos atuam para ajudar a reproduzir o poder e o privilégio dos grupos responsáveis e definir as posições dos desafiantes. ${ }^{8}$ Enquanto os grupos responsáveis se beneficiam da maior parte dos campos, os grupos desafiantes ganham certa estabilidade ao sobreviver, apesar de terem um nível mais baixo de recursos. ${ }^{9}$ Os momentos de construção das instituições ocorrem quando grupos de atores sociais se confrontam uns aos outros em algum cenário de interação social de contestação. Esses momentos são inerentemente políticos e dizem respeito a lutas por recursos escassos por parte de grupos detentores de diferentes níveis de poder. Os momentos de construção das instituições originam-se das crises dos grupos existentes (ou, na linguagem da teoria dos jogos, equilíbrios subótimos) seja na tentativa de produzir interações estáveis seja quando as regras atuais não servem mais a seus propósitos.

Instituições estáveis podem ser desenvolvidas de várias formas. Alguns grupos chegam para dominar e impor um conjunto de regras e relações a outros grupos. Uma força externa, como um governo (que também é composto de campos), pode exercer a ordem e privilegiar a si mesma ou a seus grupos mais favorecidos. Algumas vezes, os grupos podem desenvolver uma coalizão política para negociar um resultado que proporcione regras para esses grupos, como sugerido pela teoria dos jogos. Se uma situação é suficientemente fluida e muitos grupos começam a aparecer, é possível para atores sociais hábeis ajudar grupos a superar suas diferenças propondo uma nova identidade para o campo. É importante reconhecer que a construção de instituições pode fracassar. Diferentes interesses e identidades de grupos podem impedir o surgimento de instituições estáveis.

Uma dos maiores sacadas dos "neo-institucionalistas" é que grande parte da dinâmica da sociedade moderna vem das difíceis relações entre grupos desafiantes e responsáveis; da luta entre grupos responsáveis, dentro e através dos campos, para estabelecer e montar campos; e das conseqüências, intencionais ou não, causadas por essas lutas em campos adjacentes (Silber, 1995). Essas lutas podem ser entendidas como "jogos", isto é, interações sociais orientadas no sentido de produzir resultados para cada grupo. A possibilidade de novos campos depende de os atores utilizarem entendimentos existentes para criar novos campos. Seu ímpeto para isso é com freqüência baseado em sua situação atual, como desafiantes ou como responsáveis. A possibilidade de mudar a situação coletiva de um grupo pode causar a invasão de um campo próximo ou a tentativa de criar um novo.

Os campos são construídos pela utilização da "cultura" de três maneiras. Primeiro, as práticas sociais preexistentes, que incluem leis, definições de recursos e regras relevantes, e a habilidade dos atores de explorar tecnologias organizativas (por exemplo, tecnologias que criam várias tipos de organizações formais) influenciam a construção do campo. Em segundo lugar, as regras de cada campo são únicas e estão imersas nas relações de poder entre os grupos; elas funcionam como o "conhecimento local" (Geertz, 1983). Finalmente, os atores possuem estruturas cognitivas que utilizam quadros culturais, semelhantes ao que Bourdieu (1977) chama de "habitus", para analisar os significados das ações dos outros. Esses quadros ajudam os atores a decidir "o que se passa" e quais as ações disponíveis à medida que as interações se desenrolam (Hays, 
1994). Uma vez estabelecidos, os campos e as posições sociais que eles definem restringem as ações e opções de conjuntos de atores. Isso não significa, contudo, que os significados e as hierarquias dos campos não sejam objetos de contestação. De fato, a ação em campos estáveis é um jogo no qual os atores são constituídos por recursos e em que as regras são determinadas. Nas interações entre o mais e o menos poderoso, o jogo para o mais poderoso é reproduzir a ordem.

A teoria dos campos pode ser facilmente relacionada ao problema estrutura-agente. Ao se concentrar na construção de ordens sociais locais, a teoria dos campos faz com que os analistas concentrem sua atenção na maneira como grupos específicos chegam a definir um domínio social. Uma vez estabelecidas, essas definições podem ser utilizadas pelos grupos dominantes para reproduzir suas vantagens de forma periódica. É mais fácil, assim, compreender o problema da reprodução de estruturas sociais existentes. Os grupos dominantes, que podem ser identificados em uma determinada arena de ação, trabalham para reproduzir sua posição. Os grupos desafiantes tentam explorar as oportunidades apresentadas a eles na interação e por crises geradas seja na lógica interna do campo seja pelas ações de membros de campos próximos. A estabilidade ou, nos termos de Giddens, a reprodução resulta quando, conforme o jogo se desenrola, os grupos dominantes reproduzem seu poder.

A transformação de campos é possível quando os equilíbrios atuais começam a se romper, o que normalmente é precipitado por algum tipo de crise. As crises podem se originar nas relações entre grupos em um determinado campo. Com mais freqüência, a crise deriva de outros campos ou da invasão de grupos em um campo específico. Os campos se formam, primeiramente, quando grupos mais poderosos são capazes de construir uma ordem social local. Isso pode ser imposto a outros grupos ou negociado com outros grupos poderosos dentro ou fora do campo.

A teoria dos campos tem uma enorme vantagem analítica sobre as visões sociológicas convencionais, que promoveram pouca teorização sobre os campos de ação social. Ela oferece uma visão de como as ordens locais são criadas, sustentadas e transformadas. Essa teoria ajuda os acadêmicos a observar ordens específicas para determinar quais forças externas a um determinado campo estão em funcionamento. Ela também permite que os acadêmicos analisem em que condições e quando os grupos em um campo podem, de fato, criar novas ordens. Ao substituir um foco sobre a dimensão meso da ação, as teorias "neoinstitucionalistas" sugerem uma teoria radical da sociedade. Aqui, a sociedade consiste em um número poten- cialmente ilimitado de campos, que são constantemente criados e destruídos. Isso abre a possibilidade de teorizar mais claramente sobre as ligações entre campos. A idéia de campos pode ser utilizada em vários estudos empíricos. Em economia, os campos são consistentes com as visões atuais de mercados de produção na organização industrial (Gibbons, 1992). Na sociologia política, os domínios políticos são arenas da ação política (Laumann e Knoke, 1987). Na sociologia de mercados, os produtores definem os mercados como campos (White, 1981; Fligstein, 1996). Finalmente, a teoria dos movimentos sociais, com seu foco em responsáveis e desafiantes nas arenas políticas, muitas vezes implica uma metáfora para o campo (Gamson, 1975).

\section{CRÍTICA}

Os "neo-institucionalistas" discordam no que se refere aos papéis dos atores, da cultura e do poder. Em um extremo, a escolha racional sugere que as instituições são o resultado das interações de atores racionais individuais em situações semelhantes a jogos de regras e recursos fixos (por exemplo, Axelrod, 1984). Em outro extremo, os institucionalistas sociológicos se concentram, por sua vez, no fato de que os mundos sociais são obscuros e requerem interpretações, e de que as ações podem ou não ter conseqüências (Meyer e Rowan, 1977). Para lidar com isso, os atores utilizam roteiros prontamente disponíveis, muitas vezes fornecidos por governos ou profissionais, para estruturar suas interações (Jepperson, 1991; DiMaggio e Powell, 1983).

A crítica tanto da perspectiva sociológica quanto da escolha racional que eu gostaria de fazer sugere que nenhuma delas está aberta para o problema da ação nem concede às pessoas reais a possibilidade de criar seus mundos sociais. Uma teoria sociológica da ação precisa levar a sério as visões do ator racional no sentido de que os atores de fato buscam seus interesses e se envolvem agressivamente em interações estratégicas. Contudo, ela deve "socializar" os atores para coletivizá-los, e motivar suas ações fazendo com que eles orientem seu comportamento estratégico aos grupos. ${ }^{10}$

As concepções sociológicas da ação no neo-institucionalismo sugerem que as instituições fornecem significados coletivos pelos quais ocorre a estruturação do campo. Uma vez estabelecidos, esses significados fornecem aos atores roteiros para interpretar as ações dos outros e as ações para reproduzir seus grupos sociais. A maioria das análises neo-institucionalistas na sociologia começaram 
com ambientes institucionalizados. Uma vez que um conjunto de crenças ou significados é compartilhado, esse argumento sugere que os atores o disseminam ou reproduzem, consciente ou inconscientemente. Como os atores muitas vezes não podem conceitualizar nenhuma alternativa, utilizam os mitos racionalizados existentes no que se refere a suas situações para estruturar e justificar suas ações (DiMaggio, 1988).

Infelizmente, a teoria da ação nesse modelo faz dos atores "incompetentes" culturais (Giddens, 1984), transformando-os em receptores passivos das instituições. Significados compartilhados tornam-se a força causal na discussão, e os atores são os transmissores que divulgam esses significados aos grupos. Meyer e alguns de seus alunos (Meyer et al., 1987) levaram essa discussão a seu extremo lógico argumentando que a vida social no Ocidente pode ser responsabilizada pelo mito do individualismo, que produz tanto a estabilidade social quanto a mudança nos campos. ${ }^{11}$

A maioria das versões da teoria neo-institucionalista na sociologia organizacional não é acompanhada de uma teoria do poder, que se relaciona com o problema da teoria da ação. As questões 'por que os campos devem existir' e 'no interesse de quem eles existem' nunca são focalizadas pelas teorias institucionais. A dinâmica e a análise dos campos raramente dizem respeito ao poder (exceção feita à versão de Bourdieu para a teoria [Bourdieu, 1977; Bourdieu e Wacquant, 1992]), a quem se beneficia ou não. A teoria da ação encoraja esse distanciamento das questões do poder fazendo dos atores propagadores de significados compartilhados e seguidores de roteiros. Se os atores são agentes de mitos racionalizados, muitas vezes conduzidos por profissionais, eles são deixados sem "interesses", e ficamos a nos perguntar: por que eles atuam? Em função da falta de uma teoria real de interação e poder, a maioria das versões do neo-institucionalismo na sociologia não consegue explicar nem mesmo o surgimento das instituições (Powell e DiMaggio, 1991; DiMaggio, 1988; Scott, 1996; Colignon, 1997). De onde vêm as oportunidades para essas novas formas de ação? Quais atores podem organizar? Quais significados estão disponíveis e quais não estão e por quê? Por que e como os atores que deveriam apenas ser capazes de seguir roteiros reconhecem essas situações e criam novas instituições?

Isso também cria problemas que vão contra as teorizações sociais atuais, tanto na teoria da escolha racional quanto na sociologia recente. O modelo neo-institucionalista da ação na sociologia simplesmente não se envolve na afirmação da escolha racional de que as pessoas têm motivos para agir, isto é, que elas buscam algum conceito de seus interesses e agem em relação aos outros para obtêlos. As discussões teóricas na sociologia, nos últimos 15 anos, implicam que a produção e a reprodução de conjuntos atuais de regras e distribuições de recursos dependem do desempenho hábil dos atores que utilizam seu poder social e conhecimento para agir por si próprios e contra os outros (Giddens, 1984; Bourdieu, 1977; Bourdieu e Wacquant, 1992; Sewell, 1992). Os atores, em condições institucionais tanto estáveis quanto instáveis, não são simplesmente levados pelos significados compartilhados em seus campos, entendidos como roteiros que devem ser interpretados por profissionais ou burocratas do governo. Em vez disso, eles atuam com um certo nível de habilidade social para reproduzir ou contestar sistemas de poder e privilégio. E o fazem como membros ativos de um campo cuja vida está imersa no campo e dele depende.

As teorias da escolha racional na economia e na ciência política são fortes em salientar como os atores se unem, quais são seus motivos e como e por que produzem instituições. Entretanto, os modelos da escolha racional e da teoria dos jogos também apresentam teorias problemáticas de poder e ação. Pelo fato de os atores serem conceitualizados como indivíduos, mesmo quando representam coletividades, a natureza das arenas sociais e o papel dos atores em produzir, manter e assumir posições nessas arenas não recebem um embasamento teórico suficiente. Os estados, os processos políticos em geral e o poder são considerados como regras e recursos. Isso forma as bases sobre as quais os atores racionais desenvolvem seus jogos.

O problema básico é que essas teorias deixam de abordar o fato de os atores (tomadores de decisão, gestores, líderes ou elites) terem muitos constituintes para equilibrar e devem continuamente estar conscientes de que precisam produzir equilíbrio para induzir a cooperação tanto com seus aliados quanto com seus oponentes. ${ }^{12}$ Assim, por exemplo, os atores em grupos desafiantes precisam manter seus grupos unidos e continuar a motiválos a cooperar. Os modelos de ator racional, ao tratarem as regras e os recursos como sendo exógenos e os atores como sendo indivíduos com preferências fixas, deixam de abordar a criatividade e a habilidade necessárias para que os indivíduos, como representantes das coletividades, atuem politicamente em relação aos outros atores para produzir, reproduzir e transformar os equilíbrios institucionais.

Os cientistas políticos e os sociólogos orientados pela escolha não racional se frustram, com freqüência, pelo fato de os teóricos da escolha racional não se interessarem pelos detalhes dos processos sociais históricos nos quais os arranjos são feitos. Se a vida social é fundamen- 
talmente construída socialmente, então as identidades, os interesses e as ações devem ser construídos à medida que o processo emerge (Steinmo et al., 1992, capítulo 1). Isso significa que o processo social é inerentemente importante na constituição de instituições. Entretanto, essa falta de interesse no processo social na teoria da escolha racional deriva exatamente de seu modelo de ação. Uma vez que as regras e os recursos existentes são conhecidos e os interesses dos atores são determinados, a habilidade de formar instituições pode ser deduzida das regras do jogo. De fato, o modelo da teoria dos jogos não se sustenta se esse não for o caso (Tsebelis, 1990). A negociação real nos grupos e entre eles e seus efeitos na constituição de interesses são rejeitados a priori como tendo possivelmente conseqüências para o resultado.

As minhas críticas implicam a necessidade de uma concepção alternativa da ação. Aqui, os atores interessam porque alguns precisam ajudar os grupos a decidir quais são seus interesses e identidades e a se envolver em negociações entre grupos. Essa visão mais sociológica sugere que, para induzir a cooperação para formar instituições, os atores sociais devem ter a necessária habilidade, que chamo de habilidade social. É a habilidade social de atores-chave que permite que os grupos funcionem; é sua habilidade de induzir a cooperação entre os atores ao definir os interesses e as identidades coletivas que permite o surgimento e a reprodução das instituições.

\section{HABILIDADE SOCIAL COMO MICROFUNDAMENTO}

Meu objetivo nesta seção é caracterizar uma visão mais sociológica daquilo que as pessoas fazem em organizações e grupos. Não considero isso uma teoria, mas sim um grupo de percepções conceituais que ajuda a esclarecer, de um ponto de vista sociológico, o que os atores fazem em grupos e organizações. A habilidade social pode ser definida como a capacidade de induzir a cooperação nos outros. Atores sociais hábeis se relacionam empaticamente com as situações das outras pessoas e, ao fazê-lo, são capazes de fornecer a essas pessoas razões para cooperar (Mead, 1934; Goffman, 1959, 1974). Atores sociais hábeis devem compreender a percepção dos conjuntos de atores de seu grupo em relação às suas múltiplas concepções de interesse e identidade, bem como a percepção dos atores dos grupos externos. Eles utilizam essa compreensão em situações específicas para proporcionar uma interpretação da situação e determinar ações que estejam de acordo com os interesses e as identidades existentes. ${ }^{13}$

Esse conceito de habilidade social se origina na intera- ção simbólica (Mead, 1934; Goffman, 1959, 1974; Joas, 1996). As concepções dos atores de si mesmos são altamente moldadas por suas interações com os outros. Ao interagir, os atores tentam criar um senso positivo de si mesmos ao se envolverem em produzir significado para si e para os outros. As identidades se referem a conjuntos de significados que os atores possuem e que definem quem eles são e o que querem em uma determinada situação. Atores em posições dominantes que são eficazes e bemsucedidos podem ter uma boa auto-estima. ${ }^{14}$ Atores em posições dominadas podem ser estigmatizados e forçados a se envolver em estratégias de enfrentamento para contestar sua estigmatização (Goffman, 1963). Como Giddens (1984) observou, todos os membros da sociedade são capazes de desempenhos sociais hábeis. As pessoas aprendem a interagir com as outras, cooperar e ganhar um senso de identidade no processo da socialização.

Mead (1934) demonstra que alguns atores sociais são melhores do que os outros em induzir a cooperação. Isso ocorre por serem capazes de criar um senso positivo de identidade que ressoa entre os outros. A eles chamo de atores socialmente mais hábeis. Os atores sociais hábeis produzem significado para os outros porque, ao fazêlo, produzem significado para si mesmos. Seu senso de eficácia não vem de alguma concepção estreita de interesse próprio (apesar de os atores hábeis tenderem a se beneficiar materialmente de sua habilidade), mas do ato de induzirem a cooperação e ajudarem os outros a obter seus fins. Eles farão o que for necessário para induzir a cooperação, e, se um caminho estiver fechado, escolherão outro. Isso significa que os atores sociais hábeis não se limitam a seus interesses próprios e não têm metas fixas. Eles não têm interesses individuais fixos, mas, por outro lado, se concentram em desenvolver os fins coletivos. Mantêm suas metas de certa forma abertas e estão preparados para aceitar o que o sistema lhes der. Isso faz com que os atores estratégicos hábeis se comportem mais ou menos com motivações opostas às dos atores racionais, que se limitam a buscar seus próprios interesses e metas em uma espécie de competição com os outros.

Ter mais habilidade social implica que alguns atores são melhores em obter a cooperação do que outros porque algumas pessoas poderão compreender melhor uma determinada situação e produzirão significado compartilhado para os outros, conseguindo sua cooperação (Mead, 1934). Todos os seres humanos precisam de habilidade social para sobreviver. Todos nós conhecemos pessoas que são socialmente mais habilidosas do que outras; isto é, possuem a habilidade de promover a cooperação dos outros. Elas estão presentes em universidades, na política 
e no mundo dos negócios. Algumas vezes essas pessoas são líderes ou gestores com posições formais de poder, mas isso não significa que todos os "gestores" tenham um alto nível de habilidade social. A afirmação aqui é apenas de que algumas pessoas têm maior capacidade de induzir a cooperação do que outras. ${ }^{15}$

A idéia de que algumas pessoas são mais eficazes do que outras em induzir a cooperação nos outros, entretanto, é abstrata. Há dois problemas que precisam ser resolvidos para tornar essa idéia empiricamente útil. O primeiro é a necessidade de especificar que tipo de táticas os atores socialmente hábeis utilizam para induzir a cooperação. Isso permitirá que os acadêmicos empiricamente orientados reconheçam quem são os atores socialmente hábeis e procurem as várias táticas que eles possam utilizar para conseguir a cooperação. Então, é necessário relacionar mais estreitamente o uso dessas táticas à posição dos atores nos campos. ${ }^{16} \mathrm{~A}$ teoria da habilidade social nos indica o caminho para estudar a formação, a estabilidade e a transformação dos novos campos.

A literatura identificou várias táticas importantes utilizadas pelos atores socialmente hábeis (Padgett e Ansell, 1992; Bourdieu, 1977; White, 1994; Coleman, 1988; Leifer, 1988; Nee e Ingram, 1997; DiMaggio, 1988; Fligstein, 1997; Goffman, 1959, 1974). O problema básico dos atores sociais hábeis é compor "histórias" que ajudem a induzir a cooperação das pessoas de seu grupo que apelem à sua identidade e a seus interesses, e ao mesmo tempo utilizar essas mesmas histórias para desenvolver ações contra vários oponentes. Esse é o problema geral dos quadros, identificado por Goffman (1974).

Uma das fontes mais importantes para os quadros é a autoridade direta para dizer a alguém o que fazer. Weber (1978), há muito tempo, observou que a autoridade era a probabilidade de um comando direto ser obedecido com base na posição de legitimidade da pessoa que comanda. Ao sustentar uma posição em um determinado grupo social, os atores acharão mais fácil obter a cooperação dos outros. Contudo, mesmo se tiver uma posição formal em um grupo, ainda é preciso induzir a cooperação nos subordinados (Barnard, 1938). Isso significa que deve haver um repertório de outras táticas que os atores hábeis utilizam para estruturar as interações com pessoas dentro de um grupo e entre grupos.

A definição da agenda é a habilidade de definir para os outros os parâmetros da discussão (Kingdon, 1984; Lukes, 1974). Se um ator hábil puder fazer com que os outros aceitem os termos da discussão, metade da negociação já estará ganha. A definição da agenda normalmente é obtida por meio de uma ação nos bastidores para convencer múltiplos atores e grupos de que uma determinada agenda é de seu interesse. Quando os grupos se encontram, definem-se a agenda e os termos da discussão, e estabelecemse a identidade e os interesses dos atores. Isso requer que os atores compreendam seus interesses em certos limites e definam algumas ações.

Os atores hábeis entendem as ambigüidades e as certezas do campo e as exploram. Eles têm um senso do que é possível e do que é impossível. Se a situação lhe proporciona oportunidades não planejadas mas que podem resultar em algum ganho, o ator hábil as usará, mesmo se não tiver certeza de sua utilidade ou do ganho. Essa abordagem pragmática para obter a cooperação é semelhante ao que Levi-Strauss chama de bricolage (1966). O resultado é que o ator hábil aceitará o que o sistema lhe oferece a qualquer momento, mesmo que não seja exatamente o que o ator ou os outros possam idealmente querer.

De fato, os atores sociais hábeis muitas vezes acabam convencendo os outros de que o que conseguem é o que eles querem. Para isso, os atores hábeis precisam convencer os outros, que não compartilham necessariamente os mesmos interesses, de que o que ocorrerá é consistente com sua identidade e seus interesses. Isso pode ser feito persuadindo os outros a aceitar certos valores prioritários ou convencendo-os de que o que ocorrerá estará de acordo com seus interesses, pelo menos de uma certa forma. Como interesses e preferências podem ser formados ao mesmo tempo que os campos, é necessário relacionar quadros mais amplos às concepções de interesse existentes no grupo.

O ator social hábil se envolverá em intermediar mais do que as disputas (Gould, 1993). Isso ocorre de duas formas. Primeiro, os atores estratégicos se apresentam como neutros em uma situação como se estivessem apenas tentando fazer a mediação entre dois grupos. Depois, os atores estratégicos se apresentam como mais ativos em vender a identidade coletiva do grupo e motivar os outros a encontrar uma forma de unir as pessoas. Sua solução é vendida para ajudar a manter a paz ou para se certificar de que o campo como um todo não entre em colapso. Para ser intermediários, os atores hábeis precisam convencer os outros de que não se limitam aos interesses próprios e que os outros ganharão pessoalmente se chegarem a uma solução negociada.

Uma tática de negociação comum para os atores hábeis é pressionar para obter mais do que estão dispostos a aceitar, tanto dos membros recalcitrantes do grupo quanto dos que estão de fora. Como as situações são com freqüência ambíguas, ninguém nunca poderá dizer até onde os outros estão dispostos a ir. Essa tática deve ser utilizada 
com critério: se alguém pedir demais, arrisca alienar o outro lado, e é nesse ponto que a habilidade estratégica entra em jogo.

Como o objetivo da ação hábil é obter a cooperação dos outros, os atores socialmente hábeis parecem difíceis de decifrar e sem valores orientados para o benefício pessoal (isso é o que Padgett e Ansell [1992] e Leifer [1988] chamaram de ação robusta). Se os outros pensarem que alguns atores querem algo e que agem meramente em benefício próprio, eles podem facilmente determinar ações para impedir esses atores. Por outro lado, se um ator parece estar aberto às necessidades dos outros e não comprometido com alguma ação, os outros considerarão a situação mais atraente para a negociação e estarão mais dispostos a permitir a intermediação ou ajudar a forjar uma identidade coletiva.

Um problema central para os atores socialmente hábeis é encontrar uma forma de unir atores ou grupos com preferências amplamente diferentes e ajudar a reorganizar essas preferências. Esse processo de agregação, uma vez desencadeado, pode assumir vida própria. Quando um grande número de atores entra em cena, os outros os seguirão. O truque é trazer um número suficiente em cena e manter o ritmo para que outros continuem aderindo. Isso normalmente é feito ao se tentar criar uma identidade coletiva comum (Ansell, 1998). Essa identidade permite que os grupos unam as percepções divergentes de seus interesses num projeto comum.

Os atores hábeis muitas vezes manterão várias bolas no ar. Enquanto a maioria das coisas não tiver sucesso, bastam algumas vitórias para convencer os outros a aderir. Posteriormente, outros atores ou grupos só se lembrarão dos sucessos, e deve-se tentar muitas opções, esperando que algumas funcionem. Faz parte dessa ilusão de ação tentar convencer os outros de que a visão deles contém mais realidade do que eles possam imaginar. Se for possível convencer os outros de que possuem mais poder, controle ou habilidade para fazer com que outros cooperem, então, quando algo for posto em funcionamento, todos seguirão esse exemplo.

Outra tática dos atores estratégicos é fazer com que os outros acreditem que os atores estratégicos não estão no controle. Uma das táticas de ação mais engenhosas é armar situações nas quais outros atores assumam a liderança e ajam de acordo com o que pensam ser as idéias deles. Ao fazer com que os atores que estão relativamente isolados cooperem e ao convencê-los de que sua cooperação foi idéia deles, os atores estratégicos conseguem a cooperação dos outros sem parecer maquiavélicos.

Padgett e Ansell (1992) demonstraram que uma boa forma de obter a cooperação de grupos muito diferentes é fazer alianças com as pessoas que têm menos opções ou isolar os grupos mais divergentes e particularmente difíceis. A ação preferível é incluir o tantos grupos divergentes quanto possível no campo e fazer com que eles concordem com uma identidade coletiva. Uma boa forma de fazer isso é ser o núcleo da rede para esses grupos divergentes. Assim, o ator hábil é a fonte de informações e de construção de coalizões. Às vezes, certos atores ou grupos podem ser tão perturbadores que a melhor tática é o isolamento. Se estiverem perturbados e houver muitos atores perturbados mas isolados, eles geralmente permanecem desorganizados. Como esses tipos de atores costumam ser incapazes de ação estratégica por si sós, permanecem isolados.

\section{HABILIDADE SOCIAL E A ANÁLISE DOS CAMPOS}

A habilidade social funciona como uma microestrutura para compreender o que os atores fazem nos campos. Para começar, é a combinação de recursos, de regras preexistentes e das habilidades sociais dos atores que funciona para produzir campos, estabilizá-los periodicamente e produzir a transformação. Os atores sociais hábeis ajustam suas ações dependendo da organização atual do campo, sua posição nesse campo e os movimentos atuais dos atores hábeis de outros grupos no campo. O processo social é importante porque, mesmo em campos estáveis, os atores sociais hábeis precisam manipular regras e recursos para auxiliar a reprodução das ordens locais. Na próxima seção, descrevo o que podemos esperar que os atores sociais hábeis façam em diferentes condições estruturais de regras estáveis e diferentes posições no sistema de poder de um campo. Forneço algumas proposições para descrever a relação conceitual entre os atores sociais hábeis, seus recursos no campo e a organização do campo. Elas não têm o intuito de ser proposições causais, mas sim ferramentas conceituais para auxiliar a análise empírica.

\section{SURGIMENTO DOS CAMPOS E A HABILIDADE SOCIAL}

O surgimento de novos campos ocorre quando um número significativo de membros de diferentes grupos percebe novas oportunidades. A crise dos novos campos reflete o fato de que não surgiram regras estáveis de interação e que os grupos estão ameaçados de extinção. Os atores sociais hábeis orientarão suas ações para estabilizar in- 
ternamente seu grupo e estabilizar a relação do grupo com os outros grupos. É importante notar que, nessas situações, os atores sociais hábeis podem fracassar. Os atores hábeis podem não ser capazes de desenvolver coalizões políticas ou podem ser membros de grupos fortes o suficiente para impingir uma ordem social local. Toda a habilidade social do mundo pode falhar em produzir a ordem se ninguém puder reivindicar os recursos com força suficiente e não houver possibilidade de desenvolver quadros em comum.

Proposição 1: Atores sociais hábeis são fundamentais para o surgimento de novos campos. Eles devem encontrar uma forma de aplicar os recursos e regras existentes na produção de ordens locais convencendo seus partidários a cooperar e encontrando meios de acomodação com outros grupos. ${ }^{17}$

A ordem pode ser produzida de duas formas. Os maiores e mais poderosos grupos podem impor uma ordem à sua própria imagem. Nessa situação, os recursos e regras preexistentes levados ao campo emergente pelos grupos podem ser suficientes para impor uma ordem no novo campo. Isso requer que os atores estratégicos, para estabelecer uma nova ordem, utilizem as regras e recursos existentes muitas vezes com base no poder dos outros campos. É possível que um único grupo possa fazer isso se for forte o suficiente. Contudo, com freqüência, há mais que um grupo forte. Nesse caso, os grupos mais poderosos devem encontrar uma forma de cooperar para impor essa ordem. Os atores estratégicos hábeis podem negociar ou sinalizar suas intenções a seus concorrentes principais e encontrar, coletivamente, uma forma de impor uma ordem sob seu poder. Nessa situação, os recursos superiores de um pequeno número de grupos ganham a batalha. Essa situação requer ação social hábil porque os grupos precisam ser convencidos de que não ter uma ordem é pior do que uma ordem na qual eles possam estar em desvantagem.

Proposição 2: Atores sociais hábeis podem ajudar a produzir quadros culturais completamente novos para seus campos. Isso é feito construindo-se identidades de comprometimento que unem muitos grupos. Nesse processo, podem ser transformadas todas as identidades e os interesses de um grupo.

A segunda forma de produzir a ordem envolve atores hábeis inspirados, chamados por DiMaggio (1988) de empreendedores institucionais, que elaboram novos conceito culturais para ajudar a fabricar instituições completamente "novas". O truque é obter coalizões políticas sob uma nova bandeira que una grupos muito diferentes. As novas concepções culturais são desenvolvidas com base no material disponível aos atores estratégicos para propiciar, aos atores coletivos, identidades que repercutem em suas concepções coletivas de ser. Esses novos conceitos culturais podem reorganizar as identidades e os interesses dos atores. Ao decidir quem e como ser, os grupos aceitam uma posição na ordem que pode redefinir quem são e o que querem. Também ocorre de essas situações muitas vezes serem forças políticas cujos conceitos culturais unem grupos muito diferentes.

Isso possibilita que novas e inimagináveis coalizões surjam com base em novos quadros culturais (como exemplo, veja Ansell, 1998). ${ }^{18}$ Esse processo muitas vezes surge em movimentos sociais nos quais os interesses, as identidades e as preferências dessas organizações emergem a partir da interação. Aqui, os empreendedores institucionais são capazes de envolver muitos grupos em um projeto de construção de significado que pode levar estabilidade ao campo.

\section{HABILIDADE E REPRODUÇÃO SOCIAL}

A habilidade social proporciona um esclarecimento útil para o problema da reprodução social. Atores sociais hábeis em campos estáveis ou estão tentando reproduzir sua dominância ou estão tentando encontrar oportunidades para contestar a dominância dos outros. Em grupos dominantes, os atores sociais hábeis devem garantir a cooperação dos membros em seus grupos e nos grupos dominantes. Enquanto continuarem a garantir recompensas para os membros do grupo, os atores sociais hábeis provavelmente manterão seu poder.

Proposição 3: Atores sociais hábeis de grupos responsáveis em campos estáveis utilizarão os recursos e as regras existentes para reproduzir seu poder.

Os campos existentes dão aos atores responsáveis mais chances de reproduzir sua vantagem justamente porque implicam uma distribuição desigual de regras e recursos. Se os atores estratégicos hábeis forem atraídos às posições de poder nos grupos responsáveis, sua energia será direcionada para jogar o "jogo". Os atores sociais hábeis ajustam seus movimentos em relação aos outros com o objetivo de elevar ou manter a posição de seu grupo no campo.

As relações entre grupos dominantes são complexas. Periodicamente, pode-se esperar que os atores hábeis que 
lideram grupos dominantes tentarão melhorar sua posições em relação aos seus principais desafiantes. Isso também funcionará bem com outros membros do grupo, que perceberão seus líderes como tentando obter vantagens de suas relações com os outros. Assim, os atores hábeis em grupos dominantes estarão constantemente pressionando os limites das regras atuais que produzem a ordem. Os atores estratégicos hábeis precisam tomar cuidado para não questionar a ordem existente por meio de um confronto direto demais com outros grupos dominantes principais. Essa interação pode criar uma tensão permanente em um campo e a percepção de que o campo está sempre em algum tipo de crise.

Proposição 4: Atores sociais hábeis em grupos desafiantes tentarão criar nichos e explorar o que o sistema lhes dá para evitar grupos dominantes em campos estáveis, visando manter seu grupo unido e suas esperanças de desafio vivas.

Os atores estratégicos hábeis em grupos dominados enfrentam problemas difíceis em tempos de estabilidade. Provavelmente serão os grupos em maior desvantagem devido às ações estratégicas hábeis de grupos dominantes e de seus atores estratégicos. Afinal, sua posição é a mais frágil, e se os grupos dominantes quiserem obter alguma vantagem, devem escolher confrontar não outros grupos dominantes, mas os dominados. Mesmo assim, os atores estratégicos hábeis devem manter seu grupo unido. Devem encontrar uma identidade para seu grupo a fim de manter a colaboração das pessoas. Muitas vezes, a identidade é de oposição e "nicho". Os atores estratégicos hábeis em grupos dominados tendem a explorar o que o sistema lhes fornece.

Proposição 5: Em campos em que há pouca turbulência interna ou ameaça externa, é possível que a habilidade social seja menos importante para a reprodução de grupos.

É possível, em campos estáveis, que os atores possam ter menos importância para a reprodução do campo. Afinal, os grupos dominantes têm os recursos e as regras a seu favor, e os dominados têm menores oportunidades. Isso é especialmente verdadeiro quando há poucos grupos dominantes, quando há recursos ociosos no campo ou quando o sucesso e o fracasso são de avaliação difícil (por exemplo, em escolas ou delegacias de polícia). Nesse caso, a legitimidade das organizações no sentido de seu direito de existir raramente pode ser desafiada (Meyer et al., 1981), e mesmo quando há uma crise, as organizações não se retiram do negócio. Também ocorre que esses tipos de campos adquirem um status "tido como certo" pelos participantes e desafiantes potenciais.

\section{HABILIDADE SOCIAL E A TRANSFORMAÇÃO DOS CAMPOS}

Há campos que entram em crise como resultado de mudanças ocorridas fora deles, especialmente campos dependentes de um determinado campo. Assim, uma regressão dos negócios em um fornecedor ou do mercado principal de um campo, ou, no caso de governos, uma guerra ou crise econômica, terá conseqüências para uma ordem local específica. As crises podem com freqüência ser causadas por ações intencionais ou não de governos ou pela invasão de um campo por elementos externos. É possível identificar uma crise real em um campo existente como uma situação na qual os grupos principais estão tendo dificuldades em reproduzir seu privilégio já que as regras que governavam a interação não estão mais funcionando.

Proposição 6: Atores hábeis de grupos dominantes geralmente defendem o status quo mesmo em uma crise.

Os atores estratégicos hábeis em grupos dominantes começarão a agir em uma situação de crise tentando defender o status quo. Isso ocorre por duas razões. Primeiro, é difícil distinguir uma crise que ameaça a legitimidade do campo como um todo de uma subversão "normal" das regras do "jogo". Os atores estratégicos hábeis reagem às ações dos outros no campo, desafiantes ou responsáveis, envolvendo-se em ações que sempre funcionaram de forma vantajosa. A segunda razão é que, como essas ações sempre reforçaram a posição dos grupos dominantes, os atores hábeis continuarão a utilizá-las. Os atores hábeis, portanto, manipularão os mesmos símbolos, identidades e táticas que sempre tiveram sucesso no passado.

Se isso falhar ao longo do tempo e grandes grupos dominantes começarem a deixar de se reproduzir, surgirão possibilidades de novas formas de ação estratégica. Os desafiantes podem encontrar uma oportunidade (o que as teorias dos movimentos sociais [Tarrow, 1998] chamam de uma "oportunidade política") para forçar mudanças na ordem existente. Eles podem se aliar a outros grupos dominantes, a invasores de outros campos ou ao governo para ajudar a reconstituir um determinado campo. Ocasionalmente, os responsáveis podem passar para o lado dos desafiantes e ajudar a produzir mudanças no campo. 
Proposição 7: Novos quadros surgirão de atores hábeis tanto do grupo invasor quanto do desafiante. Eles tentarão criar novas regras e uma nova ordem, e assim desenvolverão uma nova coalizão política com base no interesse ou criarão um novo quadro cultural que reorganizará os interesses e identidades.

A fluidez social dessa situação indica que são possíveis novas negociações. Isso faz com que a situação seja similar à que ocorre no momento do surgimento. Assim, os grupos maiores ainda podem ser capazes de impor uma ordem, ainda que baseada em princípios diferentes. Contudo, novas instituições têm mais chances de ser tomadas por grupos desafiantes ou invasores por serem as únicas que não são comprometidas com a ordem antiga. Os que defendem o status quo podem aceitar uma nova ordem e adotar uma posição diferente nessa ordem. Contudo, isso exigirá que seus líderes mudem de identidade e interesses para justificar sua nova posição.

\section{ESCOPO DAS TEORIAS INSTITUCIONAIS}

Até agora a discussão da habilidade social e da construção de campos se manteve no nível da abstração. A teoria da habilidade social e dos campos é aplicável a uma série de fenômenos sociológicos que compartilham características comuns. É possível, portanto, considerar o escopo empírico das idéias propostas neste artigo. Os subcampos da sociologia que são mais bem analisados a partir dessa perspectiva contêm grupos organizados que possuem razões para determinar regras para um espaço social específico. Esses grupos e seus líderes possuem certa identidade coletiva, alguma concepção de interesse e uma visão que os levará a organizar seus campos. Depois de analisar quais subcampos parecem mais relevantes para esses tipos de análises, apresento alguns casos empíricos desses subcampos contrastantes. O propósito desses casos é ilustrar como algumas das idéias que desenvolvi já informam a essência acadêmica desses subcampos. Isso implica que há mais possibilidade de criar uma teoria institucional geral do que provavelmente imagina a maioria dos acadêmicos que estudam esses problemas.

Na sociologia, os subcampos em que atores autoconscientes lutam para organizar grupos com fins coletivos são: a política organizada; movimentos sociais cujas metas são transformar campos políticos e sociais existentes; a economia, em que empresas e governos criam mercados; e o setor sem fins lucrativos de economias capitalistas, em que grupos organizados produzem campos orientados para a organização de determinados setores da sociedade. Todas essas arenas de ação contêm atores que querem construir instituições para orientar suas interações de forma que suas identidades e interesses coletivos possam evoluir. Eles querem criar novos espaços sociais nos quais seus grupos possam dominar ou prosperar. Em todos esses territórios empíricos, observamos organizações formais, leis e práticas informais que orientam a interação. Sem dúvida, as metas dos atores são muito diferentes entre estados, mercados, setores sem fins lucrativos e movimentos sociais, porém, em todas essas arenas, minha afirmação é que os atores estão lutando para obter a cooperação em seus grupos e para estabilizar as interações entre os grupos.

Meu debate sobre a generalidade das idéias de campos e a habilidade social pretende ser provocativo. Apesar de muitos acadêmicos suspeitarem que deve haver uma visão mais geral das instituições na sociologia, poucos tentaram alargar o escopo dos fenômenos aos quais esses elementos conceituais se aplicam (para uma tentativa, veja Powell, 1991). Em virtude da limitação de espaço, atenho-me a casos em que os empreendedores institucionais são fundamentais para a formação de um campo ou para a transformação de um campo existente. Discuto a crise ou a oportunidade que precipitou a construção do campo, ou o momento de transformação do campo, e depois analiso "quem" foram os empreendedores, como eles criaram uma coalizão política em torno de sua nova "identidade" para o campo e como ele se tornou institucionalizado. Os exemplos ilustram as proposições gerais anteriormente discutidas. Seleciono exemplos da sociologia política, movimentos sociais, sociologia econômica, e dos estudos de organizações sem fins lucrativos.

A política "normal" se refere a grupos bem estabelecidos que utilizam sistemas políticos para manter sua dominância sobre os campos. O institucionalismo histórico é uma abordagem ao estudo dos estados que é consistente com a teoria dos campos e dos atores hábeis (Evans et al., 1985; Steinmo et al., 1992). Para Evans et al., os estados são caracterizados como tendo diferentes capacidades. As capacidades são definidas como as habilidades de organizar ou intervir em um setor da sociedade. Para os institucionalistas históricos, os estados desenvolvem tradições de formas de intervenção ou regulamentação (Steinmo et al., 1992; Dobbin, 1994). A possibilidade de mudança política requer que os institucionalistas históricos levem em consideração a natureza da crise atual, as possíveis idéias para solucionar a crise, quem eram os desafiantes e os responsáveis e como as idéias foram utilizadas pelos empreendedores políticos para unir os desafiantes e mudar as políticas (Hall, 1992; Kingdon, 1984). 
O estudo de caso apresentado por Weir (1992) dos estímulos fiscais keynesianos durante o New Deal ilustra esses pontos. A Depressão dos anos 1930 criou uma crise política para o governo federal. Em essência, as antigas idéias que governavam a economia fracassaram e estavam em descrédito. Dois problemas impediam a transformação do campo da política econômica. Em primeiro lugar, grupos bem estabelecidos e poderosos representados pelos republicanos e pelos democratas conservadores eram contra a mudança. Em segundo lugar, qual era a alternativa? Roosevelt era, é claro, um empreendedor político. Uma das coisas que ele fez para sacudir o governo foi trazer pessoas sem autoridade ou posição formal e pedir que elas estudassem os problemas e propusessem novas soluções (Weir, 1992, p. 195-196). Ele estava disposto a tentar várias soluções para os problemas da Depressão em sua busca de encontrar uma saída. Um dos empreendedores aos quais ele deu autonomia foi Marvin Eccles, nomeado para chefiar o Federal Reserve Board. Eccles recrutou pessoas que tinham novas idéias para desenvolver a economia. Em particular, trouxe pessoas favoráveis ao desenvolvimento de planos keynesianos para o déficit orçamentário.

Essas idéias, entretanto, precisavam de uma base política para se tornarem diretrizes oficiais. Os republicanos ainda controlavam o Congresso e, como os responsáveis, favoreciam e equilíbrio do orçamento do governo e um controle mais restrito da base monetária. As idéias da intervenção keynesiana na economia demandavam um grupo desafiante para levantar a bandeira. Com o tempo, cada vez mais atores na administração Roosevelt, no movimento trabalhista e no movimento dos agricultores passaram a favorecer uma maior intervenção governamental para acabar com a Depressão. Eccles liderou esse esforço divulgando o evangelho do keynesianismo. Roosevelt permaneceu cético em relação ao valor do déficit orçamentário (Weir, 1992, p. 197). O que finalmente o fez mudar de idéia foi que isso acarretou uma coalizão política no Partido Democrático. Essas idéias propiciavam um conjunto de políticas para unir eleitores de interesses muito diferentes. Na eleições de 1934 e 1936, o Partido Democrata, com base na plataforma política de utilizar a intervenção governamental para tirar o país da Depressão, assumiu o comando do Congresso. Nesse ponto, o keynesianismo passou das margens para o centro da política federal, onde formou o projeto político central para a coalizão eleitoral do Partido Democrata.

A principal questão nas teorias dos movimentos sociais são as condições em que os grupos têm sucesso em for- mar, expressar descontentamento, agir contra grupos poderosos e reorganizar a sociedade (Gamson, 1975; Tarrow, 1998, p. 4). Políticas extralegais, não institucionais ou de movimentos sociais se dedicam a tentar abrir novos campos e criar novas capacidades políticas para os grupos desafiantes. ${ }^{19}$ Sua capacidade de sucesso é uma função de uma crise ou oportunidade política, da existência prévia de grupos com recursos que possam obter vantagens da oportunidade, e da produção de uma identidade coletiva em que grupos muito diferentes possam se unir (Tarrow, 1998, p. 6-7). Essa, claro, é uma versão da dinâmica geral dos campos apresentada aqui. Os desafiantes têm sucesso em uma crise (oportunidade política) quando são capazes de mobilizar recursos e conseguem produzir uma identidade política para unir os grupos.

O campo das relações inter-raciais nos Estados Unidos estava em processo de instabilidade na década de 1950. O declínio do sistema agrícola baseado no algodão e a mudança dos negros para as cidades do Sul apresentaram aos negros uma oportunidade política para mudar sua situação. O livro de Aldon Morris (1984) se concentra principalmente na função dos vários grupos nas mobilizações que ocorreram. Morris enfatiza como a rede preexistente de grupos religiosos propiciou tanto uma base organizacional para a mobilização quanto os jovens que puderam ser recrutados pelas organizações de direitos civis. Entretanto, seu estudo também focaliza quem eram os líderes desse movimento e que identidades eles utilizaram para ganhar partidários para sua perspectiva. Uma das questões centrais do movimento de Direitos Civis era descobrir como mobilizar as pessoas. Havia várias possibilidades para isso, mas a que acabou se destacando foi a filosofia do protesto não violento. O livro de Morris mostra como as pessoas nas igrejas e em torno delas (inclusive Clara Luper e os reverendos James Lawson e Kelly Smith, entre outros e, é claro, o reverendo Martin Luther King) desenvolveram a filosofia do protesto não violento. Essa abordagem era consistente com os valores cristãos em geral e produziu uma identidade positiva para os participantes. Foram os líderes específicos que desenvolveram essa idéia e a divulgaram aos outros. Esses líderes e a abordagem das identidades para a mobilização foram fundamentais para o sucesso do movimento.

Os mercados econômicos existentes têm sido caracterizados como campos e extensivamente estudados na literatura organizacional (Hamilton e Biggart, 1988; White, 1981; Fligstein, 1996; Hannan e Freeman, 1984; Biggart e Guillen, 1999). O caso de mudança institucional que eu gostaria de utilizar vem de Alfred Chandler, 
historiador de negócios. Em seu livro Strategy and Structure (1962), Chandler se interessa pela relação entre o que os gestores querem que as corporações façam (estratégia) e como eles conseguem fazer isso (estrutura). Seu relato da ascensão do formato multidivisional (MDF) é um dos trabalhos clássicos da teoria organizacional. Nesse caso, o campo eram as grandes corporações na economia norte-americana em torno de 1920. A crise que motivou os gestores a mudar a organização da estrutura da empresa na década de 1920 foi o fato de serem incapazes de controlar suas empresas e de elas terem se tornado cada vez mais diversificadas em seus produtos (1962, p. 6-7).

O primeiro empreendedor institucional a analisar esse problema foi Alfred Sloan, que se tornou presidente da General Motors em 1922. Sloan percebeu que as cinco divisões de produto da General Motors eram altamente diversificadas e seus líderes desconfiavam uns dos outros. Como presidente, ele tinha dificuldade de fazer com que cooperassem. Os diretores de divisão, que eram os responsáveis, hesitavam em coordenar suas atividades porque não queriam ser culpados por problemas de desempenho que estavam fora de seu controle. Nas palavras do próprio Sloan (1957), isso criava um problema político no qual os gestores não cooperavam uns com os outros compartilhando informações e tecnologia ou se envolvendo em determinações justas de preços de transferência. A solução de Sloan para o problema foi o MDF (multi-divisional format). O MDF proporcionava controle operacional sobre as divisões aos gestores de cada unidade da empresa. Eles se tornaram responsáveis pelo desempenho das divisões, que era o que todos queriam. O MDF se tornou a base pela qual Sloan pôde forjar um novo comprometimento político entre seus líderes de divisão. Então, eles ficaram livres para reorganizar cada divisão como uma operação independente, com departamentos de produção, finanças e marketing. Entretanto, o preço que pagaram por isso foi uma centralização dos controles financeiros em Sloan, utilizada para avaliar o desempenho das divisões. $\mathrm{O}$ MDF permitiu que as corporações crescessem indefinidamente em tamanho. Ao dividir suas unidades em divisões de produto, o controle poderia ser descentralizado e, ao mesmo tempo, as divisões poderiam ser monitoradas simultaneamente. Os gestores de outras empresas ficaram sabendo da solução para esse grande problema por terem participado da análise de Sloan para o problema ou ao verem seus principais concorrentes adotando a mesma solução. Esse passou a ser o formato organizacional padrão que dominou o campo das maiores corporações (Fligstein, 1985).
O setor sem fins lucrativos pode ser utilmente analisado do ponto de vista dos campos (Powell, 1991). No caso, as organizações precisam obter financiamento, isto é, recursos, e descobrir o que fazer, isto é, estruturar (DiMaggio, 1982, 1988). Esses problemas são particularmente graves ao se fundarem novos campos de empreendimento. Há toda uma literatura que relaciona as atividades filantrópicas de vários grupos na sociedade ao formato final do que essas organizações fazem. O problema é que nem sempre é claro o que essas organizações deveriam fazer. Isso faz com que o problema da estruturação, especialmente no início de novos campos, seja fundamental.

DiMaggio analisou a situação em que a orquestra sinfônica e o museu de arte foram fundados em Boston no final do século XIX. No caso dos museus de arte, as questões eram: O que seria mostrado e quem seria o público? O problema da arte apresenta a questão da alta cultura versus baixa cultura. DiMaggio demonstrou que as pessoas das classes altas, os patronos das instituições de arte, tinham interesse em marcar uma distinção entre as duas, mas que precisavam, de alguma forma, elaborar e executar esses critérios. A idéia de "alta cultura" precisava ser estruturada para ser possível determinar o que poderia se enquadrar nessa classificação e o que não poderia. Assim, por exemplo, no início os museus se viam servindo a uma função educativa para as massas e muitas vezes apresentavam reproduções, e não arte original (DiMaggio 1982, p. 304).

A visão que preponderou era representada por pessoas que DiMaggio chama de os "estetas". A perspectiva desse grupo era de que a arte era uma representação da beleza e o museu deveria ser um templo para a apreciação da arte, não um veículo para a educação das massas. A diretriz era adquirir e exibir apenas arte original da mais alta qualidade. Muitos defensores dessa perspectiva eram acadêmicos (profissionais). O empreendedor que liderou esse movimento no museu foi Edward Robinson, um historiador de arte de Harvard. DiMaggio conclui provando que esse elitismo oferecia um apelo às pessoas que estavam pagando pelo museu, isto é, as pessoas abastadas de Boston. A identidade conferia a elas o status de ser de "alta cultura" e reforçava sua visão de si mesmas como especiais e privilegiadas (DiMaggio, 1982, p. 317-19). Essa visão dos museus de arte passou a organizar o campo dos museus de arte nos Estados Unidos na década de 1920. Ela unia os interesses dos profissionais, que queriam manter seu status de alta cultura, e os dos patronos, que passavam a se ver como esclarecidos.

Selecionei casos nos quais os acadêmicos proporcio- 
naram evidências suficientes para determinar se houve ou não crises em um determinado campo, analisaram a definição social de crise e suas possíveis soluções, e apresentaram o papel dos empreendedores institucionais em estruturar essas novas ações para os grupos que passaram a organizar ou reorganizar campos. O fato de os próprios autores se sentirem compelidos a produzir evidências para todos esses pontos sugere que, em seus estudos, eles viram todos os processos sociais em funcionamento. Essas semelhanças fundamentais não são geradas pela elaboração da pesquisa ou perspectivas teóricas em comum. Pelo contrário, esses autores só estão tentando compreender os seus casos empíricos. Minha afirmação é que a dinâmica dos campos é central para todas essas histórias empíricas. Os atores precisaram produzir idéias e identidades, e os grupos precisaram ser mobilizados para aceitar e adotar essas identidades. Uma vez estabelecidas, essas identidades informaram as interações subseqüentes e definiram a estrutura do campo.

\section{IMPLICAÇÕES DA TEORIA PARA A PESQUISA EMPÍRICA}

Os microfundamentos da habilidade social fazem com que os pesquisadores empíricos concentrem sua atenção nos grupos que formam um campo, nas regras e recursos disponíveis aos atores hábeis e seus grupos, nas relações entre os campos e na interpretação das relações dentro de um campo e entre os campos por atores estratégicos hábeis nos grupos. É importante estudar esses atores para compreender os projetos neo-institucionais e seu potencial de sucesso ou fracasso. Os recursos e as regras proporcionam atores poderosos com ferramentas para controlar os destinos de seus grupos. Contudo, a utilização hábil desses recursos e, onde for importante, a habilidade de construir amplas coalizões políticas e novos quadros culturais que reorganizam identidades e interesses significam que os atores também são sempre importantes.

Quando se observa o surgimento ou a transformação de um campo existente, a teoria dos campos implica que é necessário identificar quem são os principais atores coletivos, quais são seus recursos e as regras que orientam a possibilidade de ação. A habilidade social implica que, em situações instáveis, alguns atores tentarão elaborar projetos institucionais alternativos para organizar o campo. A meta do analista deve ser identificar os principais projetos possíveis e quem são seus defensores. Normalmente, há somente um pequeno número de mo- delos possíveis para elaborar instituições em um campo específico. No caso de DiMaggio, por exemplo, os dois principais modelos eram o modelo no qual os museus existiam para educar o público e o modelo no qual os museus existiam para exibir objetos belos. Ao investigar como os defensores dessas possíveis ordens institucionais estruturaram seus projetos, modificaram-nos para torná-los mais atrativos aos outros e basicamente desenvolveram poderes políticos ao redor deles, o analista pode tentar ver como os grupos de empreendedores institucionais produzem novas ordens.

$\mathrm{O}$ analista também pode se sensibilizar pelo fato de alguns quadros ganharem e outros perderem. Pode simplesmente ocorrer de os grupos que se alinham em torno de um quadro específico terem poder suficiente para serem capazes de promover esse quadro em todos os outros grupos no campo. Em outras palavras, recursos e regras pré-existentes devem ser suficientes para explicar qual quadro ganha. Por outro lado, os quadros podem ser bloqueados e nenhum quadro surgir como forma de organizar um campo. Nesse caso, os atores hábeis não foram capazes de superar os pontos potenciais de rejeição ao processo. Finalmente, os atores estratégicos hábeis podem ser capazes de estruturar um quadro que de fato reorganize os interesses do grupo ao encontrar formas de criar acordos, fazendo com que os grupos mudem a concepção de seu interesse.

Há várias implicações metodológicas óbvias para a teoria dos campos e a idéia da habilidade social. Os analistas devem reservar algum tempo para procurar os empreendedores e examinar suas táticas. Como eles divulgam suas idéias, constroem coalizões políticas, persuadem os outros e criam novas identidades? Além disso, podemos observá-los reorientando seus quadros? E quem eles atraem quando aceitam o que o sistema oferece, descobrem como fazer com que os outros cooperem e percebem com quem devem cooperar? Observo que com freqüência há múltiplos empreendedores em qualquer campo. Um projeto pode ter vários defensores. As pessoas que acabam tendo sucesso em unir o campo podem não ser aquelas que iniciaram o processo.

Os acadêmicos muitas vezes acabam observando instituições estáveis quando são confrontadas por novos desafios, devido a crises provenientes de fora ou de dentro dos campos. Como estudamos a reação dos atores estratégicos em organizações responsáveis? Meu argumento é que os acadêmicos devem entender quem são os participantes em um campo, como ele funciona e quais são as ferramentas disponíveis para que os atores estratégicos reforcem o status quo. Os atores devem utilizar as ferra- 
mentas que mantenham o status quo durante uma crise. Primeiro eles negarão a existência de crise. Se isso falhar, proporão ações elaboradas para reforçar seu poder no campo. Ao final, promoverão reformas gradativas ou pequenas mudanças que manterão intacta a distribuição de poder no campo enquanto tentam cooptar a oposição ou os grupos desafiantes.

\section{CONCLUSÃo}

A idéia de habilidade social nos oferece uma forma de começar a estudar como os atores algumas vezes podem transformar as estruturas sociais mas na maioria das vezes fracassam em fazê-lo. Ela nos permite entender como recursos e regras, uma vez estabelecidos, tendem a favorecer os grupos maiores e mais organizados. A teoria dos campos nos ajuda a ver que, uma vez estabelecidos, em geral os arranjos organizacionais dominantes se reproduzem periodicamente. Isso também ocorre graças à distribuição de regras e recursos para os grupos dominantes e à habilidade dos atores hábeis em utilizá-los para reproduzir seu poder.

A reprodução do poder dos grupos nem sempre é garantida. Sempre há desafiantes para o poder social de qualquer grupo. Além disso, a base do poder de um grupo, sua reivindicação de recursos e regras, pode ser questionada em crises sociais periódicas. Essas crises podem se originar fora ou dentro do campo. À medida que as crises se intensificam, aumenta o papel dos atores sociais hábeis na reprodução de um determinado conjunto de poder social. Da mesma forma, em condições sociais mais turbulentas, em uma crise grave ou com o surgimento de um campo, os atores sociais hábeis exercem funções ainda mais visíveis. Eles elaboram quadros alternativos para a organização do campo, propagam esses quadros e convencem outros atores a cooperar para estabelecer identidades e interesses recém-definidos. À medida que os novos quadros se espalham e ganham defensores no campo, a estrutura do campo emerge e o quadro se institucionaliza para formar a estrutura do campo.

Demonstrei que as idéias sociológicas dos campos e da habilidade social oferecem muitas características atraentes. Elas reapresentam os atores nas discussões sociológicas sobre política, estado e economia. Oferecem papéis tanto para os atores quanto para as estruturas que auxiliam na compreensão de qualquer episódio de construção de campo. Além disso, elas proporcionam idéias conceituais para se estudarem esses episódios e se entender o que fazem os atores hábeis e os grupos por eles liderados. Acredito que grande parte dos nossos melhores trabalhos acadêmicos sobre os processos sociais nessas arenas sociais perceberam explícita ou implicitamente como os atores e as estruturas estão envolvidos nos momentos de construção das instituições. Ainda há muito trabalho teórico a ser feito. Este artigo proporciona uma abertura para uma teoria sociológica mais geral dos atores e das instituições. Essa teoria demandará a cooperação tanto dos acadêmicos empiricamente orientados que têm estudado o mundo social em vários contextos quanto a dos mais teoricamente orientados. De fato, sem essa cooperação, seremos incapazes de preencher a lacuna entre a teoria e a pesquisa.

\section{NOTAS}

\footnotetext{
* Uma versão deste artigo foi preparada para a conferência "Poder e organização", patrocinada pela Associação Sociológica Alemã, na Universidade de Hamburgo, em Hamburgo, Alemanha, em 9-11 out. 1997. Este artigo também foi apresentado no Departamento de Política e Sociedade da Universidade da Califórnia, em Irvine. Eu gostaria de agradecer a Victor Nee por uma conversa que me ajudou a elaborar este artigo. Chris Ansell, Frank Dobbin e Doug McAdam ofereceram comentários úteis.
}

\footnotetext{
${ }^{1}$ A questão da ação é importante em várias subáreas da sociologia: movimentos sociais, teoria organizacional, sociologia política e sociologia da cultura. Acredito que isso reflita o fato de essas áreas lidarem com a questão da mudança social, em que atores ou conjuntos de atores regularmente contestam formas estabelecidas de fazer as coisas e são capazes, por vezes, de elaborar novas orientações de ação.
}

\footnotetext{
${ }^{2}$ A teoria da habilidade social também se assemelha às idéias propostas por Anthony Giddens no que se refere à "reprodução hábil da vida social" (1984) e à noção de Hans Joas da "criatividade da ação social" (1996)
}

\footnotetext{
${ }^{3}$ Meu propósito aqui não é me envolver diretamente no debate sobre as teorias da ação, conduzido por Emirbayer e Misch (1999). Ao contrário, meu propósito é estimular o projeto conceitual de conectar uma visão particular de ação às teorias neo-institucionalistas.
}

\footnotetext{
${ }^{4}$ Para alguns exemplos, veja, em ciência política, March e Olsen, 1989; Steinmo et al., 1992; Pierson, 1995; Cox e McCubbins, 1993; Krehbiel 1991; Shepsle, 1989; em sociologia, Meyer e Rowan, 1977; Bourdieu e Wacquant, 1992; Scott, 1996; Scott e Meyer, 1983; Powell e Dimaggio 1991; Dobbin, 1994; Nee e Brinton, 1998; e, em economia, Simon, 1957; Williamson, 1985; North, 1990; Milgrom e Roberts, 1982; Jensen e Meckling, 1974.
} 
${ }^{5}$ Há, sem dúvida, discordâncias substanciais também entre as várias teorias do neo-institucionalismo. Hall e Taylor (1996) demostram que existem pelo menos três variedades de teorias neo-institucionalistas, que chamam de sociológica, institucionalismo histórico e teoria da escolha racional.

${ }^{6}$ Os estados contêm os campos nas sociedades modernas, em que as regras gerais são modeladas e colocadas em execução. Os campos fora dos estados se organizam de acordo com regras gerais da sociedade e regras locais provenientes da interação dos grupos nesses campos.

${ }^{7}$ Trata-se de uma distinção importante. As leis podem, de forma intencional ou não, criar novos campos. As práticas podem ser trazidas de outros campos. Qualquer instituição preexistente pode ser utilizada pelos atores para enquadrar interações. Esse processo de institucionalização é separado e de certa forma ortogonal à produção original das leis ou práticas. À medida que os atores interagem, podem acabar estruturando um campo que não era pretendido pelos construtores originais de instituições.

${ }^{8}$ Os responsáveis (incumbent groups) se referem aos grupos dominantes em um campo, enquanto os desafiantes (challenger groups) se referem aos grupos de fora. Esses termos foram utilizados por Gamson (1975) para descrever organizações de movimentos sociais.

${ }^{9}$ Meu foco sobre o poder não é a única maneira de entender os campos. Muitas versões da teoria institucionalista se concentram em normas ou interesses como o fator determinante da estruturação dos campos. Opto por considerar o poder e o significado a base para os campos.

${ }^{10}$ É nesse ponto que este artigo definitivamente rompe com Nee e Brinton (1998).

${ }^{11}$ Concordo com Meyer que a modernidade se refere à construção do mito do individualismo e à reconstituição dos atores, conforme demonstrei acima. Contudo, acredito que essa idéia abstrata seja apenas uma parte da história, que pode ser utilizada para justificar um grande número de ações e arranjos sociais. A maior e mais importante parte da história é o desenvolvimento de atores determinantes e tecnologias de organização e sua subseqüente utilização na construção do estado e da economia. Ademais, o propósito da construção de instituições é que conjuntos de atores produzam arenas de poder nas quais suas posições sejam reproduzidas.

${ }^{12}$ Há uma literatura da teoria da escolha racional sobre jogos de dois níveis, nos quais atores individuais atuam em constituições diferentes. Mesmo assim, essa literatura se baseia em atores individuais em busca de interesses seus próprios individuais.

${ }^{13}$ Este ponto de vista não apenas transforma a perspectiva "do outro" no que se considera que essa perspectiva seja (uma "volta"), mas é uma tentativa séria de compreender empaticamente o que o outro pensa.

${ }^{14}$ A baixa auto-estima pode estar associada também a atores eficazes. As pessoas podem ser impelidas à ação para se sentirem melhores consigo mesmas e para sentirem ligações significativas com os grupos. Entretanto, se tiverem uma auto-estima suficientemente baixa, considerarão que o "sucesso" não lhes proporciona mostras suficientes de seu próprio valor. Isso pode levá-las a continuar se envolvendo em agressivos projetos de construção de "significado", nos quais nunca conseguirão encontrar significado nem construir uma identidade positiva para si.

${ }^{15} \mathrm{Na}$ recente literatura sobre as origens e os propósitos da mente humana, observa-se que grande parte da evolução do cérebro dos primatas e dos humanos parece se relacionar ao seu alto nível de sociabilidade (Leakey, 1994, capítulo 8; Byrne e Whitman, 1988; Humphrey, 1993; Jerison, 1991). A mente e a autoconsciência funcionam, desse ponto de vista, para ajudar os primatas a acompanhar e participar da vida social. Há evidências da existência de uma identidade individual (self) em primatas não humanos (Byrne e Whitman, 1988). As evidências das pesquisas de campo sugerem que uma concepção de identidade individual pode ser deduzida da habilidade dos primatas em formar alianças e redes, cooperar e se envolver em "atos de falsidade". Nos humanos, tanto a linguagem quanto a identidade individual são mais altamente desenvolvidas. A habilidade social é uma qualidade que todas as pessoas devem ter para o progresso da vida social. Nossa habilidade de conseguir as coisas das quais precisamos, de conceitualizá-las e envolver os outros em nossa busca coletiva constitui o núcleo da vida social.

${ }^{16}$ Nem todos os atores sociais hábeis são líderes ou estão em organizações dominantes. Como todos os atores sociais possuem habilidade social, segue-se que as pessoas que estão em posições de menor poder utilizarão sua habilidade social para resistir à sua submissão, se envolverão em atos de subterfúgio e tentarão trabalhar contra os aspectos mais difíceis de suas situações.

${ }^{17}$ Essas proposições não são afirmações causais de que os atores sociais hábeis farão ou não diferença na organização de seu campo. Em vez disso, resumem expectativas quanto ao comportamento dos atores sociais hábeis em diferentes condições estruturais.

${ }^{18}$ Até agora, todas as teorias da escolha racional na economia e na ciência política têm resistido a essa idéia. Penso que isso reflete duas preocupações. Primeiro, é difícil ver como o surgimento de um empreendedor pode ser previsto, e se o sentido da teorização é fazer previsões, os empreendedores estão fora do contexto da teoria. Em segundo lugar, a teoria dos jogos estabeleceu parâmetros relativamente fixos, e é difícil imaginar como se poderia desenvolver um "jogo" cujo principal objetivo fosse transformar o próprio jogo.

Artigo originalmente publicado por Neil Fligstein, sob o título "Social skill and the theory of fields", na Sociological Theory, v. 19, n. 2, p. 105-125, 2001. Publicado com autorização da American Sociological Association. (C) American Sociological Association. http:// www.asanet.org.

\section{REFERÊNCIAS}

ALEXANDER, J.; SMELSER, N. The Micro-Macro Link. Berkeley, CA: University of California Press, 1987. 
ANSELL, C. Symbolic networks. American Journal of Sociology, v. 103, n. 2, p. 359-390, 1998.

AXELROD, R. The Evolution of Cooperation. New York: Basic Books, 1984.

BARNARD, C. The Functions of the Executive. Cambridge, MA: Harvard University Press, 1938.

BIGGART, N.; GUILLEN, M. Developing difference: social organization and the rise of the auto industry in South Korea, Taiwan, Spain, and Argentina. American Sociological Review, v. 64, n. 5, p. 722-747, out. 1999.

BOURDIEU, P. Outline of a Theory of Practice. Cambridge, UK: Cambridge University Press, 1977.

BOURDIEU, P.; WACQUANT, L. Invitation to a Reflexive Sociology. Chicago: University of Chicago Press, 1992.

BYRNE, R.; WHITMAN, A. Machiavellian Intelligence. Oxford: Clarendon Press, 1988.

CHANDLER, A. Strategy and Structure. Cambridge, MA: MIT Press, 1962.

COLEMAN, J. Social capital in the creation of human capital. American Journal of Sociology, n. 94, suplemento, p. 95-120, 1988.

COLIGNON, R. Power Plays. Albany, NY: State University of New York Press, 1997.

COX, G.; McCUBBINS, M. Legislative Leviathan: Party Government in the House. Berkeley, CA: University of California Press, 1993.

DIMAGGIO, P. Cultural entrepreneurship in nineteenth century Boston. Media, Culture, and Society, v. 4, n. 1, p. 303-322, 1982.

DIMAGGIO, P. Interest and agency in institutional theory. In: ZUCKER, L. (Ed.). Institutional Patterns and Organization. Cambridge, MA: Ballinger Press, 1988. p. 3-21.

DIMAGGIO, P.; POWELL, W. The iron case revisited. American Sociological Review, v. 48, n. 2, p. 147-160, 1983.

DOBBIN, F. Forging Industrial Policy. Princeton, NJ: Princeton University Press, 1994.

EMIRBAYER, M.; GOODWIN, J. Network analysis, culture, and the problem of agency. American Journal of Sociology, v. 99, n. 6, 1411-1454, 1994.
EMIRBAYER, M.; MISCHE, A. What is agency? American Journal of Sociology, v. 106, n. 6, p. 187-211, 1999.

EVANS, P.; RUESCHMEYER, D.; SKOCPOL, T. Bringing the State Back In. Cambridge, UK: Cambridge University Press, 1985.

FLIGSTEIN, N. The spread of the multidivisional form. American Sociological Review, v. 50, n. 2, p. 377-391, 1985.

FLIGSTEIN, N. Markets as politics: a political-cultural approach to market institutions. American Sociological Review, v. 61, n. 4, p. 656-673, 1996.

FLIGSTEIN, N. Social skill and institutional theory. American Behavioral Scientist, v. 40, n. 4, p. 397-405, 1997.

GAMSON, W. The Strategy of Social Protest. Homewood, IL: Irwin Press, 1975.

GEERTZ, C. Local Knowledge. New York: Basic Books, 1983.

GIBBONS, R. Game Theory for Applied Economists. Princeton, NJ: Princeton University Press, 1992.

GIDDENS, A. The Constitution of Society. Berkeley, CA: University of California Press, 1984

GOFFMAN, E. Presentation of Self in Everyday Life. Garden City, NJ: Doubleday Press, 1959.

GOFFMAN, E. Stigma. Englewood Cliffs, NJ: Prentice-Hall, 1963.

GOFFMAN, E. Frame Analysis. Cambridge, MA: Harvard University Press, 1974.

GOULD, R. Collective action and network analysis. American Sociological Review, v. 58, n. 2, p. 182-96, abr. 1993.

HALL, P. The movement from keynesiansim to monetarism. In: STEINMO, S. (Ed.). Structuring Politics. New York: Oxford, 1992.

HALL, P.; TAYLOR, R. Political science and the three new institutionalisms. Political Studies, v. 44, n. 5, p. 936-957, 1996.

HAMILTON, G.; BIGGART, N. Market culture and authority. American Journal of Sociology, v. 94, supplement, p. 52-94, 1988.

HANNAN, M.; FREEMAN, J. Structural inertia and organizational change. American Sociological Review, v. 49, n. 2, p. 149-164, abr. 1984. 


\section{NEIL FLIGSTEIN}

HAYS, S. Structure and agency and the sticky problem of culture. Sociological Theory, v. 12, n. 1, p. 124-42, 1994.

HUMPHREY, N. The History of the Mind. New York: Harper Collins, 1993

JENSEN, M.; MECKLING, P. The theory of the firm: managerial behavior, agency costs, and ownership structure. Journal of Financial Economics, v. 3, n. 4, p. 305-360, out. 1974.

JEPPERSON, R. Institutions, institutional effects, and institutionalization. In: POWELL, W; DIMAGGIO; P. (Eds.) The New Institutionalism in Organizational Theory. Chicago: University of Chicago Press, 1991. p. 143-163.

JERISON, H. Brain Size and the Evolution of the Mind. The 59th Annual James Arthur Lecture on the Brain. New York: American Museum of Natural History, 1991

JOAS, H. The Creativity of Action. Chicago: University of Chicago Press, 1996.

KINGDON, J. Agendas, Alternatives, and Public Policy. Boston: Little, Brown, 1984.

KREHBIEL, K. Information and Legislative Organization. Ann Arbor, MI: University of Michigan Press, 1991.

LAUMANN, E.; KNOKE, D. The Organizational State. Madison, WI: University of Wisconsin Press, 1987.

LEAKEY, R. The Origins of Humankind. New York: Basic Books, 1994.

LEIFER, E. Interaction preludes to role setting. American Sociological Review, v. 53, n. 6, p. 865-878, 1988.

LEVI-STRAUSS, C. The Savage Mind. Chicago: University of Illinois Press, 1966.

LUKES, S. Power: A Radical View. London: Macmillan, 1974.

MARCH, J.; OLSEN, J. Rediscovering Institutions. New York: Free Press, 1989

MEAD, G. H. Mind, Self, and Society. Chicago: University of Chicago Press, 1934.

MEYER, J.; BOLI, J.; THOMAS, G. Ontology and rationalization in the Western cultural account. In: THOMAS, G.; MEYER, J.; RAMIREZ, R; BOLI, J. (Eds.). Institutional Structure: Constituting State, Society, and the Individual. Beverly Hills, CA: Sage, 1987.

MEYER, J.; ROWAN, B. Institutionalized organizations: formal structure as myth and ceremony. American Journal of Sociology, v. 83, n. 2, p. 340$363,1977$.
MEYER, J.; SCOTT, W. R. Organizational Environments. Beverly Hills, CA: Sage, 1983

MEYER, J.; SCOTT, W. R.; DEAL, T. Institutional and technical sources of organizational structure: explaining the structure of educational organizations. In: STEIN, H. (Ed.). Organization and the Human Services. Philadelphia: Temple University Press, 1981.

MILGROM, P.; ROBERTS, J. Limit pricing and entry under incomplete information: an equilibrium analysis. Econometrica, v. 50, n. 2, p. 443459, mar., 1982

MORRIS, A. Origins of the Civil Rights Movement. New York: Free Press, 1984

NEE, V.; BRINTON, M. The New Institutionalism in Sociology. New York: Sage, 1998

NEE, V.; INGRAM, P. Embeddedness and beyond: institutions, exchange, and social structure. In: BRINTON, M.; NEE, V. (Eds.). The New Institutionalism in Sociology. New York: Sage, 1997.

NORTH, D. Institutions, Institutional Change, and Economic Performance. Chicago: University of Chicago Press, 1990.

PADGETT, J.; ANSELL, C. Robust action and the rise of the Medici. American Journal of Sociology, v. 98, n. 6, p. 1259-1320, 1992.

PIERSON, P. When effects become cause: policy feedbacks and political change. World Politics, v. 45, n. 4, p. 595-628, 1995.

POWELL, W. Expanding the scope of institutional analysis. In: POWELL, W.; DiMAGGIO, P. (Eds.). The New Institutionalism in Organizational Theory. Chicago: University of Chicago Press, 1991.

POWELL, W.; DIMAGGIO, P. The New Institutionalism in Organizational Analysis. Chicago: University of Chicago Press, 1991.

SCOTT, R. W. Institutions and Organizations. Beverly Hills, CA: Sage, 1996

SCOTT, W. R.; MEYER, J. The organization of societal sectors. In: MEYER, J.; SCOTT, R. W. (Eds.). Organizational Environments. Beverly Hills, CA: Sage, 1983. p. 129-53.

SEWELL, W. A theory of structure: duality, agency, and transformation. American Journal of Sociology, v. 98, n. 1, p. 1-29, 1992.

SEWELL, W. A Rhetoric of the Bourgeois Revolution: The Abbe Sieyes and What Is the Third Estate. Durham, NC: Duke University Press, 1994.

SHEPSLE, K. Studying institutions: some lessons from the rational choice approach. Journal of Theoretical Politics, v. 1, n. 2, p. 131-147, 1989. 
SILBER, I. Spaces, fields, boundaries. Social Research, v. 62, n. 2, p. 323355,1995

SIMON, H. Administrative Behavior. New York: MacMillan, 1957.

SLOAN, A. My Years at General Motors. New York: Basic Books, 1957.

SNOW, D.; ROCHFORD, E. B.; WORDEN, S. K.; BENFORD, R. Frame alignment processes, micromobilization, and movement participation. American Sociological Review, v. 51, n. 4, p. 464-481, 1992.

STEINMO, S.; THELEN, K.; LONGSTRETH, F. Structuring Politics: Historical Institutionalism in Comparative Perspective. New York: Cambridge University Press, 1992.

TARROW, S. Power in Movements. Ithaca, NY: Cornell University Press, 1998.
TSEBELIS, G. Nested Games. Berkeley, CA: University of California Press, 1990.

WEBER, M. Economy and Society. Berkeley, CA: University of California Press, 1978.

WEIR, M. Ideas and the politics of bounded innovation. In: STEINMO, S. et al. (Eds.). Structuring Politics. New York: Cambridge University Press, 1992.

WHITE, H. Where do markets come from? American Journal of Sociology, v. 87, n. 3, p. $517-547$, nov. 1981.

WHITE, H. Identity and Control. Princeton, NJ: Princeton University Press, 1994.

WHITE, H. The Economic Institutions of Capitalism. New York: Free Press, 1985.

WILLIAMSON, O. Markets and Hierarchies. New York: Free Press, 1975.

Artigo convidado. Aprovado em 20.02.2007.

\section{Neil Fligstein}

Professor do Departamento de Sociologia da University of California - Berkeley.

Interesses de pesquisas nas áreas de sociologia econômica, organizações e sociologia

política.

E-mail: fligst@berkeley.edu

Endereço: Department of Sociology, University of California, Berkeley - California,

94720, USA. 